\title{
Introduction to the Field of Cytometry and its Importance in Biomedicine
}

\author{
Rafael Nunez* \\ Associate Laboratory Member, Memorial Sloan-Kettering \\ Cancer Center, Box 98, 1275 York Avenue, New York, \\ NY 10021, USA
}

Flow cytometry is a methodology for determining and quantitating cellular features, organelles or cell structural components primarily by both optical and electronic means. Although it measures one cell at a time, the newest equipment is able to process up to several hundred thousand cells in a few seconds. Flow cytometry can be used to count and even distinguish cells of different types in a mixture by quantitating their structural features. Therefore, flow cytometry has great advantages compared to traditional microscopy since it permits the analysis of a greater number of cells in a fraction of the time. In addition cell sorting with flow cytometers has been a powerful tool for diverse fields in biomedical research and clinical applications.

\section{What is Flow Cytometry and its importance?}

Since the early 1970's, flow cytometers that do not employ fluorescence have been commercially available. They were initially used for complete blood cell counts in clinical laboratories. Their ease of handling and reliability of results increased and popularized their use. The newest and most versatile research instruments employ fluorescence; these are named flow cytofluorometers. The world-wide utilization of flow cytometry is demonstrated by the occurance of flow cytometric data in almost any issue of a scientific journal concerned with cell biology. In addition, a large percentage of research papers in the fields of biomedical sciences and immunology report flow cytometric data. About 46,400 citations containing flow cytometry information have been compiled to date by MEDLINE (March, 2001).

Flow cytometers are widely found in all leading biomedical research institutions and universities where they are used for performing tasks that require analytical precision and high throughput. In addition, flow cytometers have a key role in hospital and medical centers worldwide, where they are widely used for diagnosis as well as research. There are several thousand flow cytofluorometers in clinical use worldwide. The major diagnostic applications being ploidy, cell cycle and surface analysis of cancers. They are also of use in the study of surface markers of lymphomas and leukemias which are of diagnostic and prognostic value. Flow cytometry also has been the method of choice for monitoring the progression of AIDS and the

*For correspondence. Email nunezr@mskcc.org; Tel. (212) 639-6392; Fax. (917) 432-2333. response to treatment by measuring CD4 lymphocyte levels in the blood. Less expensive alternative technologies are not yet available for performing such tasks in clinical and research settings. In addition, sorting and high speed sorting are becoming increasily important in the performance of research, clinical trials, clinical applications and teaching (1-10).

\section{How Does It Work?}

The cells prepared in a monodisperse (single cell) suspension may be alive or fixed at the time of measurement. They are passed through a chamber as single cells. The fine stream containing the cellular suspension is passed through the chamber as a continuous flow. The cells inside the chamber are excited by the beam of the laser(s) light. Each cell scatters some of the laser light, as well as emitting fluorescent light following excitation by the laser. The signal of the scattered light and the signal of the emitted fluorescence are collected for analysis. The cytometer typically measures several parameters simultaneously for each cell:

i) Forward scatter intensity (FSC) is approximately proportional to cell diameter.

ii) Side scatter intensity (SSC) or orthogonal (90 degrees) scatter is approx-imately proportional to the quantity of granular structures within the cell.

iii) Fluorescence intensities are measured at several wavelengths.

FSS alone is often quite useful. It is commonly used to exclude dead cells, cell aggregates, and cell debris from the fluorescence data. It is sufficient to distinguish lymphocytes from monocytes or from granulocytes in blood leukocyte samples. Side scatter has been used in our laboratory to assess granularity of living cells such as Dendritic cells.

Fluorescence intensities are typically measured at several different wavelengths simultaneously for each cell. Fluorescent probes, generally coupled to antibodies, are used to report the quantities of specific components of the cells. Fluorescent antibodies are often used to report the densities of specific surface receptors, and thus to distinguish subpopulations of differentiated cell types, including cells expressing a transgene or cells expressing a unique marker.

The binding to surface receptors of viruses, or diverse proteins such as hormones, can also be measured by making them fluorescent. Intracellular components can also be reported by using fluorescent probes. For example, measurement of total DNA per cell will allow cell cycle analysis. Also, cytometric determination of newly synthesized DNA or identification of specific nucleotide sequences in DNA or mRNA can be accomplished. 
Filamentous actin or any structure for which an antibody is available can be determined by cytometry $(1,2,5,9)$.

Flow cytometry can also be used to measure rapid changes in intracellular free calcium, membrane potential, $\mathrm{pH}$, or free fatty acids. In addition, flow cytometry can be used for measurement of the metabolic status of cellular membranes and to study mitochondria functionality (1).

Flow cytometers involve sophisticated handling of fluids and pressure, complex laser beams and optics, very sensitive electronic detectors, analogue to digital converters, and high capability computers. The optics deliver laser light inside the chamber focused to a beam a few cell diameters in size. The fluidics hydrodynamically focus the cell stream within a margin of a small fraction of a cell diameter, and, even in sorters, break the stream into uniform-sized droplets in order to separate individual cells. The electronics quantitate the faint flashes of scattered and fluorescent light, and, under computer control, select the electrically charged droplets containing cells of interest so that they can be deflected into a separate test tube or culture wells. The computer is able to record data for thousands of cells per sample, and displays the data graphically $(3,7,8,10)$.

The sorting applications have evolved from obtaining a few cells to complex applications like the selection of cells for single cell analysis and/or the bulk collection of cells with unique characteristics that will be analyzed or transferred into a recipient $(1,2,8,9)$.

\section{References}

1. Robinson, J.P. 1998. Current Protocols in Cytometry. John Wiley \& Sons, Inc. New York.

2. Coligan, J.E. 1998. Current Protocols in Immunology. John Wiley \& Sons, Inc. New York.

3. CellQuest software reference manual. 1997. Becton Dickinson immuno-cytometry systems.

4. Watson, J. 1998. Purdue Cytometry CD-ROM. Volume 4, Purdue University Cytometry Laboratories. http:// www.cyto.purdue.edu

5. Ormerod, M. 1999. Flow cytometry. Bios Scientific, ISBN: $185996107 X$.

6. Ormerod, M. Data Analysis in Flow Cytometry: A Practical Approach. A CD-ROM.

http://ourworld.compuserve.com/homepages/ Michael_Ormerod.

7. Steinkamp, J. 1984. Flow cytometry. Rev. Sci. Instrum. 55: 1375-1400.

8. The Art of Fluorescent Activated Cell Sorting: Research Notes from Becton Dickinson Order number 23-213700.

9. Givan, AL. 1992. Flow Cytometry: First Principles. Wiley-Liss, New York.

10. Bagwell CB. 1993. Theoretical Aspects of Data Analysis. In: Clinical Flow Cytometry Principles and Application. Ed Bauer KD, Duque RE and Shankey TV. Pages 41-61. 


\section{Further Reading}

Caister Academic Press is a leading academic publisher of advanced texts in microbiology, molecular biology and medical research. Full details of all our publications at caister.com

- MALDI-TOF Mass Spectrometry in Microbiology Edited by: M Kostrzewa, S Schubert (2016) www.caister.com/malditof

- Aspergillus and Penicillium in the Post-genomic Era Edited by: RP Vries, IB Gelber, MR Andersen (2016) www.caister.com/aspergillus2

- The Bacteriocins: Current Knowledge and Future Prospects Edited by: RL Dorit, SM Roy, MA Riley (2016)

www.caister.com/bacteriocins

- Omics in Plant Disease Resistance Edited by: V Bhadauria (2016) www.caister.com/opd

- Acidophiles: Life in Extremely Acidic Environments Edited by: R Quatrini, DB Johnson (2016) www.caister.com/acidophiles

- Climate Change and Microbial Ecology: Current Research and Future Trend

Edited by: J Marxsen (2016)

www.caister.com/climate

- Biofilms in Bioremediation: Current Research and Emerging Technologies

Edited by: G Lear (2016)

www.caister.com/biorem

- Microalgae: Current Research and Applications Edited by: MN Tsaloglou (2016) www.caister.com/microalgae

- Gas Plasma Sterilization in Microbiology: Theory, Applications, Pitfalls and New Perspectives Edited by: H Shintani, A Sakudo (2016) www.caister.com/gasplasma

- Virus Evolution: Current Research and Future Directions Edited by: SC Weaver, M Denison, M Roossinck, et al. (2016) www.caister.com/virusevol

- Arboviruses: Molecular Biology, Evolution and Control Edited by: N Vasilakis, DJ Gubler (2016) www.caister.com/arbo

- Shigella: Molecular and Cellular Biology Edited by: WD Picking, WL Picking (2016) www.caister.com/shigella

-Aquatic Biofilms: Ecology, Water Quality and Wastewater Treatment

Edited by: AM Romaní, H Guasch, MD Balaguer (2016)

www.caister.com/aquaticbiofilms

- Alphaviruses: Current Biology

Edited by: S Mahalingam, L Herrero, B Herring (2016)

www.caister.com/alpha

- Thermophilic Microorganisms

Edited by: F Li (2015)

www.caister.com/thermophile
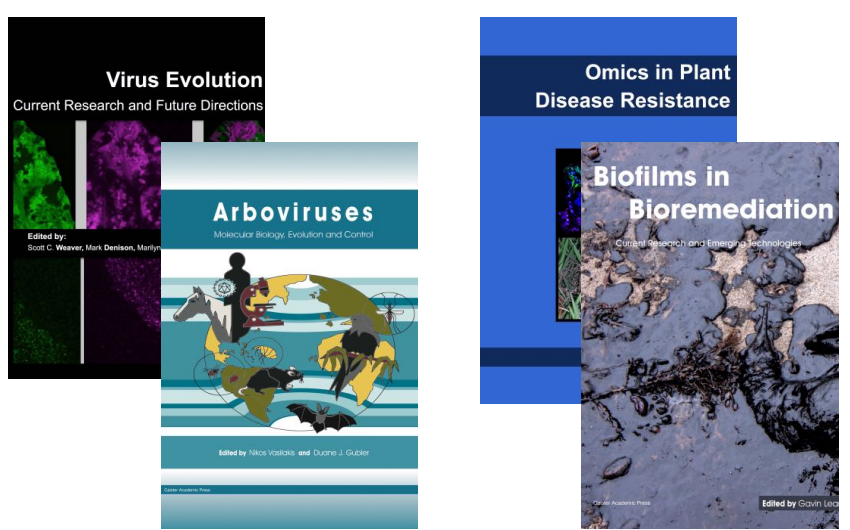
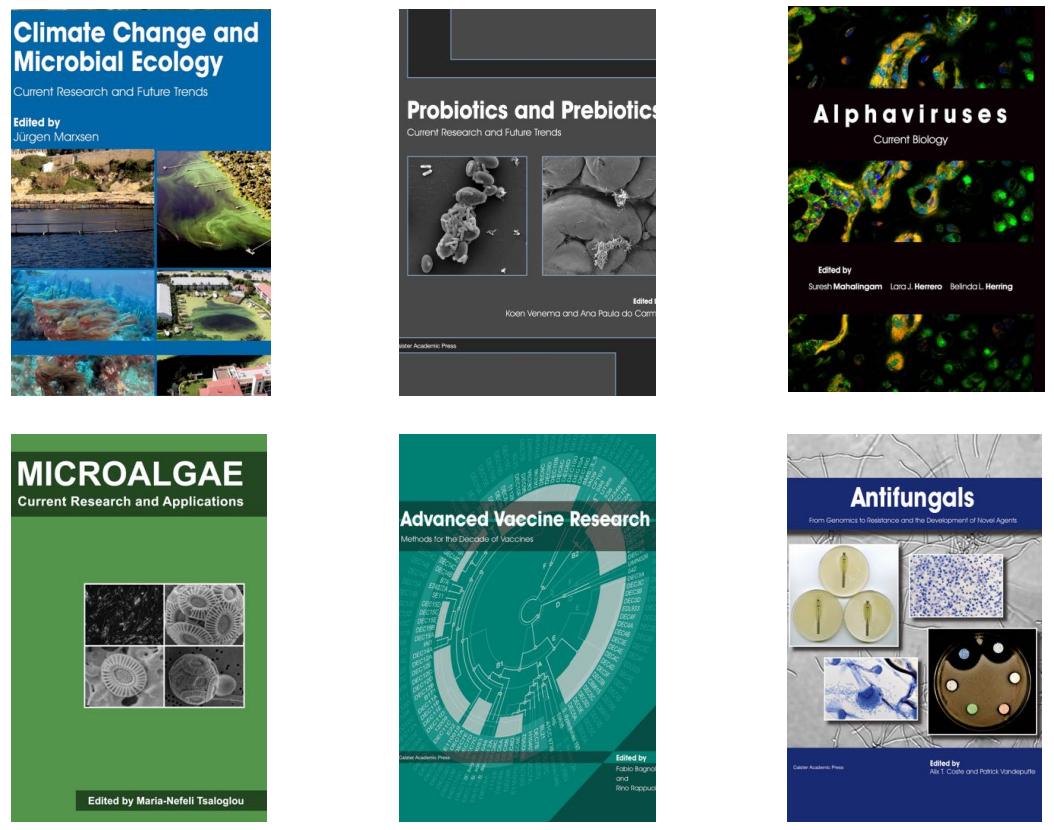

- Flow Cytometry in Microbiology: Technology and Applications Edited by: MG Wilkinson (2015) www.caister.com/flow

- Probiotics and Prebiotics: Current Research and Future Trends Edited by: K Venema, AP Carmo (2015) www.caister.com/probiotics

- Epigenetics: Current Research and Emerging Trends Edited by: BP Chadwick (2015) www.caister.com/epigenetics2015

- Corynebacterium glutamicum: From Systems Biology to Biotechnological Applications

Edited by: A Burkovski (2015)

www.caister.com/cory2

- Advanced Vaccine Research Methods for the Decade of Vaccines

Edited by: F Bagnoli, R Rappuoli (2015)

www.caister.com/vaccines

- Antifungals: From Genomics to Resistance and the Development of Novel Agents

Edited by: AT Coste, P Vandeputte (2015)

www.caister.com/antifungals

- Bacteria-Plant Interactions: Advanced Research and Future Trends Edited by: J Murillo, BA Vinatzer, RW Jackson, et al. (2015) www.caister.com/bacteria-plant

\section{- Aeromonas}

Edited by: J Graf (2015)

www.caister.com/aeromonas

- Antibiotics: Current Innovations and Future Trends

Edited by: S Sánchez, AL Demain (2015)

www.caister.com/antibiotics

- Leishmania: Current Biology and Contro Edited by: S Adak, R Datta (2015) www.caister.com/leish2

- Acanthamoeba: Biology and Pathogenesis (2nd edition) Author: NA Khan (2015)

www.caister.com/acanthamoeba2

- Microarrays: Current Technology, Innovations and Applications Edited by: Z He (2014)

www.caister.com/microarrays2

- Metagenomics of the Microbial Nitrogen Cycle: Theory, Methods and Applications

Edited by: D Marco (2014)

www.caister.com/n2 